\title{
THE ARCHITECTURE OF CONSTRUCTIVISM: THE CREATIVE TRANSFORMATION OF AESTHETIC CODES AND NARRATIVES
}

\author{
Larisa PISKUNOVA ${ }^{1}$, Liudmila STAROSTOVA ${ }^{2}$, Igor YANKOV 3 \\ ${ }^{1}$ Institute of Social and Political Sciences, Ural Federal University, Lenina str. 51, \\ Yekaterinburg 620000, Russia \\ ${ }^{2}$ Institute of Public Administration and Entrepreneurship, Ural Federal University, Lenina str. 13b, \\ Yekaterinburg 620014, Russia \\ ${ }^{3}$ Independent researcher
}

Received: 14 June 2017; accepted 19 March 2018

\begin{abstract}
The architecture of constructivism (functionalism) has a kind of symbolic meaning associated with the modernist project. The authors conducted a study of the architectural avant-garde of Sverdlovsk, Russia which showed that the weak perception of the historical and cultural importance of constructivist buildings and complexes is associated not only with the lack of the people awareness and creativity, but also with the underestimation of their aesthetic value.

Meanwhile, the study of space-planning solutions for specific architectural projects reveals really conceptual aesthetics of the buildings. In addition, the study of the social history of constructivist architectural complexes, conducted by the authors, helped us to identify and articulate their cultural and historical significance and to highlight in a creative way the visual perception of these architectural reference markers in the space of the city. The authors also rely on their own experience of the exhibition, publication and sightseeing activities. The analysis of this experience allows the authors to draw some conclusions about the practice of developing and shifting the visual perception of constructivist monuments by the people.

The originality of the presented approach to the study of architecture is an appeal to the social history of architecture which helps to enhance its aesthetic value.
\end{abstract}

Keywords: aesthetic code, avant-garde architecture, city, constructivism, narrative, social experience.

\section{Introduction}

The architectural heritage of the Soviet avant-garde (constructivism) today is in the focus of attention of historians of Soviet architecture (Buchli, 2013; Cohen, 1992; Smirnov, 2008; Starkov, Selivanova, \& Zueva, 2016; Tokmeninova, 2012; Khan-Magomedov, 2001; Meerovich, 2008), as well as the representatives of the cultural sphere involved in its promotion. Meanwhile, historical buildings themselves are often in a depressing state: they need major

${ }^{\star}$ Corresponding author. E-mail: starostova5@mail.ru

This is an Open Access article distributed under the terms of the Creative Commons Attribution License (http://creativecommons. $\mathrm{org} / \mathrm{licenses} / \mathrm{by} / 4.0 /$ ), which permits unrestricted use, distribution, and reproduction in any medium, provided the original author and source are credited. 
repairs and restoration, their walls are shabby, they are poorly covered in popular media, and therefore their aesthetic significance is perceived as questionable by the townspeople.

The authors set themselves the task of analyzing narrative practices devoted to the avantgarde architecture of Sverdlovsk built in the late 1920s and mid-1930s, referring to the understanding of Soviet avant-garde architecture codes and integrating it into the modern cultural contexts. The exhibition project dedicated to the social history of these architectural complexes, as well as the practice of visual conversion of a significant marker of Sverdlovsk constructivism - the Iset Hotel - within the framework of the art project of the Ural Industrial Biennial of Contemporary Art (UIBCA) were chosen as an object of analysis. The objective of the exhibition project was to integrate the architectural heritage of the city with the modern codes and narratives, make them understandable for the modern audience, as one of the objectives of the event project was to attract the attention of citizens to the forgotten items of constructivist architecture.

\section{Languages of describing architecture as a part of the urban environment}

Architecture and the urban environment as a whole can be considered as a semiotic text bearing different meanings in accordance with different codes (Eco, 2006). The city appears as a palimpsest of various texts, interacting and intersecting with each other in different hierarchical and related relationships (Genette, 1998a, 1998b). The problem of reading and interpreting is related to the topic of code selection. Some codes are naturalized and perceived as natural, taken for granted, become the basis for mythology, propaganda and ideology. This also applies to the aesthetic perception, when certain models and patterns are given as normative, correct, and some political and everyday experience of their "use" is formulated as various ways of interpretation, sometimes mythologizing the item described.

Frank Ankersmit (2003a, 2003b) emphasized the issue of historical experience, framed in a narrative form. In his early works, he shows that any historical narrative is formed around some basic metaphors, and history dominance in certain versions of the description in both the scientific and popular field is associated with the struggle of competing metaphors and concepts and the victory of one of them through choice. Such an emphasis on the topic of choice creates the illusion of complete (postmodern) arbitrariness in the space of narrative choice. However, there are limitations of arbitrariness associated with the concept of experience itself. In his later work - Sublime Historical Experience - Ankersmit focuses not so much on the possibility of using the narrative to know the past, but rather on how this relationship with the past is shaped through experience (2007). The main thing is not the question of truth itself, but communication, interaction with the past.

If Ankersmit is interested in the very phenomenon of sublime historical experience and its closeness to the concept of trauma, in our study we are talking about the productivity of working with the concept of experience in an urban environment with architectural objects. In this case, of great importance for our analysis are the works of Paul Ricœur on the possibilities of reconfiguring experience through appealing to the new metaphors, concepts and ways of reading the past (2000a, 2000b), Jacques Rancière about the division of the sensual among the representatives of different social groups, each of which can have its own sensual 
experience (2007), and Charles Landry, who describes attempts to radically update the world outlook through overcoming the narrowness of thinking as a manifestation of creativity (2000). Historical experience can be managed through different readings (recoding), reconfiguration:

"of the common sensory world, proceeding from some work on its basic elements, over the form of objects of the everyday world. This general idea can also be expressed in a return to the craft, in socialism, in symbolic aesthetics, and in industrial functionalism" (Rancière, 2007, pp. 235-236).

The characteristic feature of this approach is that it allows transforming the urban narrative, urban history, through the appeal to a hidden, unmanifested experience. This means giving importance to the "invisible" experience of common people, worldly history, and the experience of the architectonic style (constructivism), once formerly official but later condemned by the Stalinist authorities. One can recall the idea of Walter Ben'yamin about the significance of history, told from the standpoint of the losers as giving them a voice (2000).

Attention to the city and architecture is associated with a growing interest in the topic of memory, national and local identity and the corresponding forms of narrative (Assman, 2015; Kačerauskas, 2008; Piskunova, Starostova, \& Yankov, 2015; Yankov, 2011). In our case, architecture appears as a structure of crystallization of a socially formed experience. Without suggesting a linear form of history, a linear narrative, this approach immerses the objects of attention in a wide context, which through recoding "breathes life" into architectural objects disappearing from the view of the modern urban dweller. Reconfiguration of experience and adjustment of optics allows working with the theme of regional identity, with the variability of regional mythology and, as a consequence, with the subsequent translation of meanings with the aim to attract different audiences - citizens, tourists, investors.

\section{Recoding of architecture in the texts of Soviet architects-constructivists}

Soviet architects-constructivists theoretically relied on the functionalism of Le Corbusier and Bauhaus, but at the same time disassociated themselves from it. As Moisei Ginzburg wrote criticizing the functionalists of the Western school, "we have a completely different task - the creation of a new social type of man" (Ginzburg, 1928, p. 143). Soviet power was aimed at the total reconstruction of society, including both socio-economic relations, culture, and the infrastructure of cities associated with the rejected capitalist world. The constructivism of the 1920s willingly picks up this pragmatics:

\footnotetext{
"The establishment of socialist construction, a new society with different industrial and domestic relations, a society that develops under our conditions is our trump card, the value of which is infinitely great" (Ginzburg, 1926b, p. 44).
}

Aleksei Gan, defining the concept of constructivism as an artistic style, which has manifested itself most vividly in architecture and printing art, emphasizes the importance of integrating the artistic idea into the overall social dynamics (2016, p. 850).

Ginzburg, who became one of the leading theorists of constructivism, paid much attention to the issues of form-building in architecture. For him, the form is not self-sufficient, its expressiveness is directly derived from function and material. Arguing about the form, 
Ginzburg did not hide his enthusiasm for the machine as the quintessence of the spirit of modernity. In the editorial article as the journal editor he states:

\begin{abstract}
"The wise economy of material and energy, the accuracy of the movement of its elements, the only possible way of their connection in each case, the laconic language of the design of these elements, the simplicity and frankness of the composition with the definitely identified axis of movement - this is the aesthetics of a modern machine, in which, of course, there are many organizing principles for the artist activity" (Ginzburg, 1923, p. 5).
\end{abstract}

For Ginzburg, the dilemma is built around the issue of functional solutions and forms. Commenting on the architectural designs of their colleagues, Vesnin brothers (projects of Palace of Labor and the Arcoshouse), Ginzburg underlines the difference between constructive solution of the building and its appearance which is really important for him:

\begin{abstract}
"Vesnin's palace" comes primarily from new social solution of building organism, thus setting the fundamental feature of Soviet constructivism [...]. Thus it is Palace of Labor that must be considered as the first milestone of genuine constructivism, while APKOC with its planar system of verticals and horizontals, with the clarity of its proportions, restrained simplicity of the whole and the parts is a perfectly made thing, but devoid of a genuinely revolutionary impact of constructivism" (1927, p. 112).
\end{abstract}

From the given citations, it becomes obvious that Ginzburg considers the constructivist method as a design of space, which stimulates new practices and relations. Commenting on the projects of his colleagues, he drew attention to the obvious dilemma between the detached form and the modeling of a new social content. If the form is self-sufficient, it is superfluous and thus distorts the very essence of the new architecture. Therefore, the analysis of formal expressiveness as such becomes meaningless. The shape of the building, its facade motivated by function and expressing this function, is the true foundation of constructivist aesthetics. This aesthetics is plastic, because each time it must obey the function of the architectural project:

"The very idea of 'decoration' of the facade, even in the very newest style, is a false and obsolete idea, since, in fact, modern architecture, the architecture expressing our new era, does not require any 'façade'. This architecture is naturally and inevitably obtained as a function of correctly understood new industrial-household relationships, new building materials and the methods of their use" (Ginzburg, 1926a, p. 90).

Of course, almost a century after the end of the era of constructivism in architecture, when one can speak of it as a finished style, historians of architecture identify a number of constructive and expressive elements that have become recognizable visual markers of this style: smooth walls, ribbon glazing, flat roof, asymmetric composition, pillars-supports at the base of the building, open lay-out. It is now easy to identify houses made in a constructivist style by these markers. However, it is impossible to understand the inner content of these visual attributes without the constructive role they played in the building design, and also without understanding the relationship of the building design to its destination within the framework of the constructivist code system. In this sense, the basic aesthetic idea of constructivism is the ability to generate new social practices and production processes. 


\section{Constructivism of Sverdlovsk/Yekaterinburg in modern narrative practices}

Yekaterinburg (from 1924 to 1991 - Sverdlovsk, named after one of the leaders of the Bolsheviks) can be proud of the rich architectural heritage of constructivism. In 1923 the Ural region was organized, and in 1925 Sverdlovsk became its capital and the center of industrialization in the Urals. Until that time, the two-storey, mostly wooden city was transformed into a regional center with the developed (in accordance with the then standards), urban infrastructure in one decade. In 1930, the general plan for the development of Sverdlovsk (project team led by Sigismund Vladislavovich Dombrovsky) was published, according to which "the city must be so built in such a way as to stimulate and organize the entire order of life, labor and production, culture, physical and mental development and upbringing, as well as the ways of rest and entertainment, the maximum development of personality" (1723.ru, 2008). The constructivist idea was placed at the very basis of the spatial planning of the city as the principle of organizing the whole life, contributing to the streaming of all social energy to solve production tasks, not only freeing the workers, but also helping to form the new type of a person, comprehensively developed, motivated to participate in joint practices and tasks.

In total, more than 400 constructivist buildings were built in the city. Today, they reflect not only the characteristic features of the style (ribbon glazing, asymmetrical compositions using multi-figure volumes, smooth walls, flat roofs, rounded corners, etc.), but also the social practices that occurred in them.

The scientific interest in the constructivist architecture of Sverdlovsk arose in the mid1970s, when the first publications appeared (Berseneva, 1972, 2000; Starikov, Zvagelskaia, \& Tokmeninova, 1998; Smirnov, 2008; Shelushinin, 1974). The closest approach to the study of constructivism is presented in the works of Victor Buchli (2013), Jean-Louis Cohen (1992), Richard Per, Jean-Louis Cohen, and Phyllis Lambert (2007), Ilya Starkov, Alexandra Selivanova, and Darya Zueva (2016), Liudmila Starostova (2016), Mikhail Timofeev (2015), Artur Tokarev (2015), Mikhail Ilchenko (2016).

Despite of the active interest of researchers to the topic of constructivism, it, nevertheless, is not perceived by the majority of the townspeople as a unique historical heritage and an important symbolic resource of the city. The efforts of many popularizers are aimed at solving this problem: guidebooks on constructivism are published, and some buildings are museumed (e.g. White Tower in Sotsgorod Uralmash, type F cell in a house designed by Ginzburg's workshop).

Summarizing various practices of working with the historical legacy of constructivism, we can divide them into several types:

- an architectural description, emphasizing the features of spatial design solutions and the external appearance of buildings;

- interactive narrative practices ("Bus number 33" - sightseeing bus on the social site of Sotsgorod Uralmash with broadcasting of interviews with the residents of the district, excursions to architectural complexes, popular science films and documentaries on constructivism);

- exhibitions, offering a detailed artistic, anthropological narratives on the avant-garde heritage of the city; 
- revitalization practices that invite citizens to enter inward abandoned constructivist spaces (the UIBCA, a cluster of restaurants and bars in the Press House and the cellars of the Chekists village).

We will dwell on the description and analysis of the last two ways of transcoding constructivist heritage, because purely architectural narrative is the most obvious way of describing; and excursions are based on borrowing information from other narratives.

A. The exhibition as a creative way of re-encoding the architectural heritage. The authors attempted to re-encode the perception of avant-garde architecture as a purely architectural phenomenon as curators of the exhibition "Villages of Sverdlovsk: From an Architectural Project to Social Experience". The exhibition opened within the framework of the Second Days of Constructivism in the Urals on October 4, 2016 and worked until November 26, 2016. The appeal to architecture as an element of social practices was conditioned not only by the generally recognized fact that architecture has always been integrated into social processes, but also by the specificity of the creative and production program of constructivism aimed at social design. The manifestation of this program in the construction of Soviet Sverdlovsk can be convincingly illustrated by the example of the master plan for the city development, that was elaborated in 1929-1930.

In addition to describing the strategic directions of spatial development, the authors of the Sverdlovsk master plan also touched on the architectural design of household practices. The central idea is the accumulation of social institutions of different profiles within the residential complex that would facilitate the relieving the stress of the formerly private life through the socialization of a number of household functions - cooking, eating, washing, caring for children, etc. According to the master plan, each complex should include: a public dining room, a nursery and a kindergarten, a laundry, an outlet for the distribution of consumer goods, a red corner (which means a small cultural club) and a reading room, a gym, baths and public showers (1723.ru, 2008).

This idea has not found a consistent manifestation in all residential complexes related to constructivism, but a few villages (as the residential constructivist complexes are usually referred to) can boast such an infrastructure. The most striking example and at the same time the full version of the material embodiment of this idea was the Chekists village, a complex built for NKVD employees in the mid-1930s, designed by the architects Ivan Antonov, Veniamin Sokolov, Arseny Tumbasov and Alexander Stelmashchuk. In the complex, there was a club with a library, a shop, a kindergarten, a laundry, a sauna, a polyclinic, a sports yard and a dining room. The apartments in Chekists village did not have kitchens, because the function of cooking was supposed to be socialized - the inhabitants of the village had to eat in the canteen. A small gas stove was envisaged in the corridor of these apartments, just to warm up some food. As shown by the study of the experience of life in the Chekists village, the idea of socialization of feeding in the village did not take root. People preferred to cook at home, thus rearranging the space to organize some area for the kitchen. Such social design is also present in other constructivist villages of Sverdlovsk.

The experience of the study of constructivism by the methods of social history (interviews, observation, collection and analysis of photographs from personal archives of people who lived in the complex at different times) allowed authors to draw the conclusions about 
the influence of the architectural project on the subsequent everyday practices of its inhabitants - the appeal to the social history of this phenomenon allows us to reveal its significance in urban history, to speak out its human experience. Constructivism is one of the forms of the embodiment of Soviet utopia, in which, over the course of several decades, the drama of interaction of people with the architectural matrix and with each other was played out under the conditions of this matrix. This conclusion predetermined the conceptual approach to the development of the exhibition "Villages of Sverdlovsk: From an Architectural Project to Social Experience" (see Figure 1).

As an object for study and exposure, five constructivist complexes of Sverdlovsk/Yekaterinburg were chosen: the City of Justice, Medical village, the Chekists village, the Houses of the Gospromural, the Houses of the Uraloblsovet.

A special feature of presenting information on the constructivist complexes of Sverdlovsk/ Yekaterinburg was the emphasis to the interaction of architecture and the communities that have been using it. The exhibited material was based on interviews with the residents of the complexes, photographs from private and state archives. During the exhibition, the curators also conducted a series of excursions around the villages in the city itself, with a mandatory visit to the apartments or work spaces of the complexes studied. This practice aroused the liveliest interest of the townspeople, who wanted to look inside the historical buildings and come into contact with their real life.

The authors have set themselves the task of constructing the image of architectural complexes, taking into account the two vectors of social interactions within them: the first vector develops in the direction of community versus architecture and allows revealing the mutual influences of the designed space and everyday practices of people who master it. The second vector of the research was aimed at revealing the social ties between people, caused by the phenomenon of the architectural complex as such. Each of the villages studied was analyzed

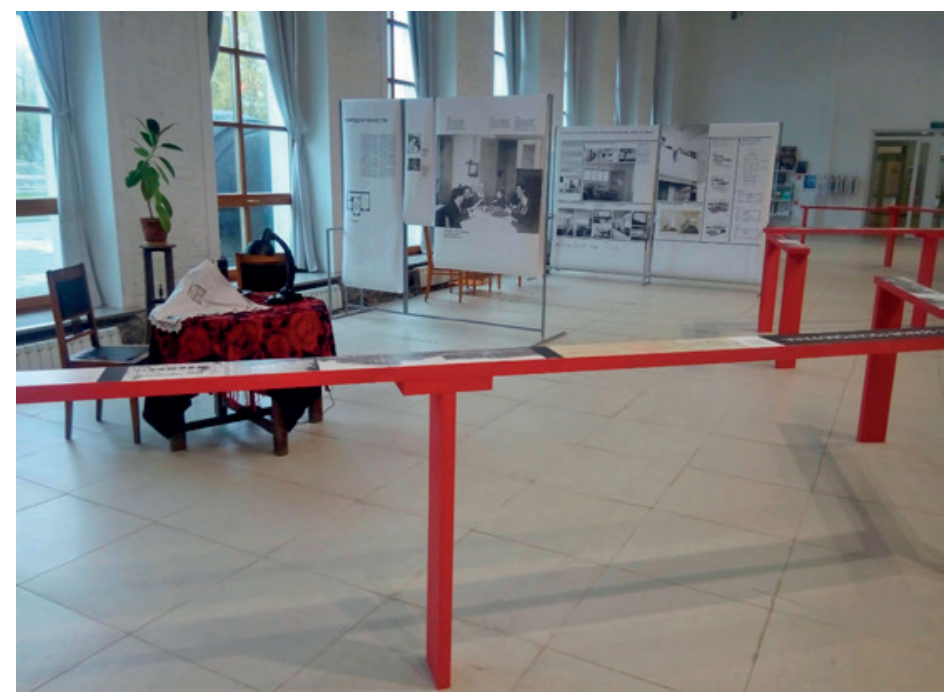

Figure 1. The exhibition "Villages of Sverdlovsk: from an architectural project to social experience". Photo by Liudmila Starostova, 2016 
in two directions of possible connections, but as the collected material showed in each of the complexes different degrees of manifestation of the phenomena under consideration were revealed.

To study the process of influence of architectural decisions on everyday practices of people, the authors followed a simple technique that involved the preliminary analysis of the architectural design in order to subsequently identify the possible impact of specific planning decisions on the everyday life. In particular, the example already described above with the organization of the kitchen zone in the apartments of the Chekists village, initially not adapted to the process of cooking, indicates the utopianism (at least in the 20th century) of the idea of socialization of feeding.

To clarify the essence of this technique, we give two examples.

As the experience of our informants and our own study of the modern layout of apartments in the Chekists village show, all of them, one way or another, have acquired a more or less sound kitchen area. Dramatic interaction with the architectural space occurred in all the villages studied - everywhere glitches occurred due to the deviation of social processes from the social model embedded in the architectural project. For example, in a complex of Uraloblsovet's houses designed by Ginzburg's workshop, one of the buildings (building No. 1) has both the spectacular constructive style solution and the unique layout of apartments-type F cells. In order to save the socialized common space, Ginzburg designed the cells so that the entrance to the cells located one above the other was from the same floor. As a result, for every three floors of the building there is only one common corridor, and the cells have a multi-level structure. Initially, a toilet with a shower and a kitchen module were designed in each cell. But when discussing the project, the local administration decided to save on equipment and placed toilets, showers and kitchens at the end of each corridor, thus making them public elements. The final result of this decision was the gradual transformation of the dormitory into the office building.

If to talk about social relations formed by an integrated approach to the development of the territory, the experience of people's lives in the so-called Village of Justice is of special interest. In many guidebooks and reference books on Yekaterinburg constructivism, the Village of Justice includes three buildings: the House of Justice (the building shared by the Regional Court and the Law Institute), a dwelling house for the employees of justice and the so-called snail house (architect Sergey Zakharov). The study of the everyday life of people who lived and worked in these buildings allowed us to draw a conclusion about the existing unified system of relations within this complex, programmed at the level of spatial planning and related to the judicial and executive sphere.

The building of the House of Justice housed two institutions: the Regional Court and the Sverdlovsk Law Institute. And although inside the building these two institutions were not connected by internal passage, passing through the street, students could get in to hear cases in court, which served as an excellent methodological aid in their education. In addition, law students earned money in the jail, and, in the 1930s, they lived in the House of Justice building. Standing next to the House of Justice is the Lawyer's house - a dwelling house for the employees of the judiciary, initially it was focused on communication with the court only. But its location close to the territory of the city prison also led to such a phenomenon 
as visual and even verbal contact of prisoners and residents of houses. So, this spatial proximity formed social connections between the subsystems of the social world, united by the infrastructure of the judicial and penitentiary system.

The interpretation of the avant-garde architectural heritage through its social history is regarded by us as a kind of transcoding of its perception. This happens through the integration of architecture in the social field of the city. In this case, the citizens look at the buildings as the materialization of the socio-cultural matrix that has formed the world of more than one generation of people. And from the point of view of the narrative, the correlation with reality through the mode of truth or lie does not matter much. The novelty and originality of history comes first in importance. In this sense, the narrative acquires a similarity to mythmaking by the criterion of the plot, although it differs greatly from the myth according to the criterion of the validity of history by factual material.

B. Art practices as a way to creative transcoding of avant-garde architecture.

The second approach to transcoding the constructivist heritage is to revitalize it through artistic events, making them sites for performances and installations. The strategy of drawing attention to the architectural heritage through the initiation of cultural events today has become quite popular (Valevičius \& Levickaitè, 2011; Quinn, 2005). This strategy of constructivism conversion is actively developed by the National Center for Contemporary Arts, which is the ideologist and organizer of the UIBCA held in Yekaterinburg from 2010. At the basis of the specialization of the Ural Biennial there is the idea of industriality as an attribute of local identity, therefore all three biennials held used the buildings and spaces of the industrial era. In 2010 and 2012, the Press House was chosen as the main exhibition site of the Biennial - a symbolic object of constructivism in the city center. In 2015, the location of biennial's main project moved to the symbolic for the Soviet Sverdlovsk building of the former Iset Hotel (the semantic dominant of the city center).

The Iset Hotel was built and functioned as the dormitory for the junior officers of NKVD; later it became a city hotel. In 1936, this building was featured at the Spanish stamp as the symbol of the new Soviet city, the new lifestyle and the new architecture.

According to the plan, the building has the shape of a horseshoe which is again due to economy. The architects tried to save on the space of the corridor in favor of the living rooms space. They arranged the rooms on the convex side of the building, and the corridor on the concave side. This ingenious planning solution gave the building its outlines, which became the guarantee of its visual expressiveness. But, now it is gradually turning off from the urban context due to the appearance of skyscrapers in the city and the opening of the new, more modern hotels. This process turns the building invisible for local people. After the disappearance of its practical functions, its symbolic meaning is also gradually disappearing.

However, in the autumn of 2015 this building again seemed to return from non-existence: within two months nine of the ten floors of the former hostel, and then the hotel, were occupied by art objects of the Biennial. On the 9th floor there was an exposition devoted to the architectural complex of the Chekists village and the Iset Hotel. A huge banner of the Ural industrial Biennial hung on the facade of the hotel.

Of particular importance in restarting the perception of the Constructivist building was the art-work Zheng Yunhan "Whisper of Light", which sealed the windows from the court- 
yard facade of the building with a thin colored film. The effect was that when the light was turned on in the building at night, the windows on the concave side shined with different colors and attracted the attention of the public. Many people came specially to the back courtyard of the village to take a photo of the building of the Iset Hotel from the side which was not considered good for taking photos before (see Figure 2).

The main part of the Biennial's visitors was the students and the representatives of creative industries, this is the social group that is active in social networks and publishes bright impressions of their life there. As a result, during the Biennial, the user accounts from Yekaterinburg were filled with photographs taken at the Biennial and comments under them.

The event organizers suggested that guests put a hashtag \#iamgoingtobiennial (\#яидунабиеннале) at the publication. We analyzed the publications in the social media Instagram during the period of the Biennial and found out that the publications from this event often caused discussion. Users asked each other about their impressions, asked to evaluate the exhibition and to recommend to visit or not to visit the Biennial. In total, the Instagram users made 1974 publications with such a hashtag. Content analysis of publications shows that not all art works have become popular as the objects of photography. The most spectacular, photogenic objects, such as "House of Thousands of Persons", "Room with Hieroglyphics", "Small City", "Comfort Zone" became the leaders of publication activity. But the leading position in the number of publications is occupied by the Iset Hotel, photos taken from the back courtyard at night. The analysis of the comments under the photos showed that in most reviews there were mixed impressions of what people saw. Many people wrote that they were not ready to perceive modern art. But at the same time it was recommended to go to the Biennial for the sake of the Iset Hotel ("To be honest: it's worthwhile to go for the sake of the Iset Hotel itself", and there is also a special atmosphere in the Iset Hotel itself: old elevators, city views, unusual layouts", “The most vivid impression is the view from the windows").

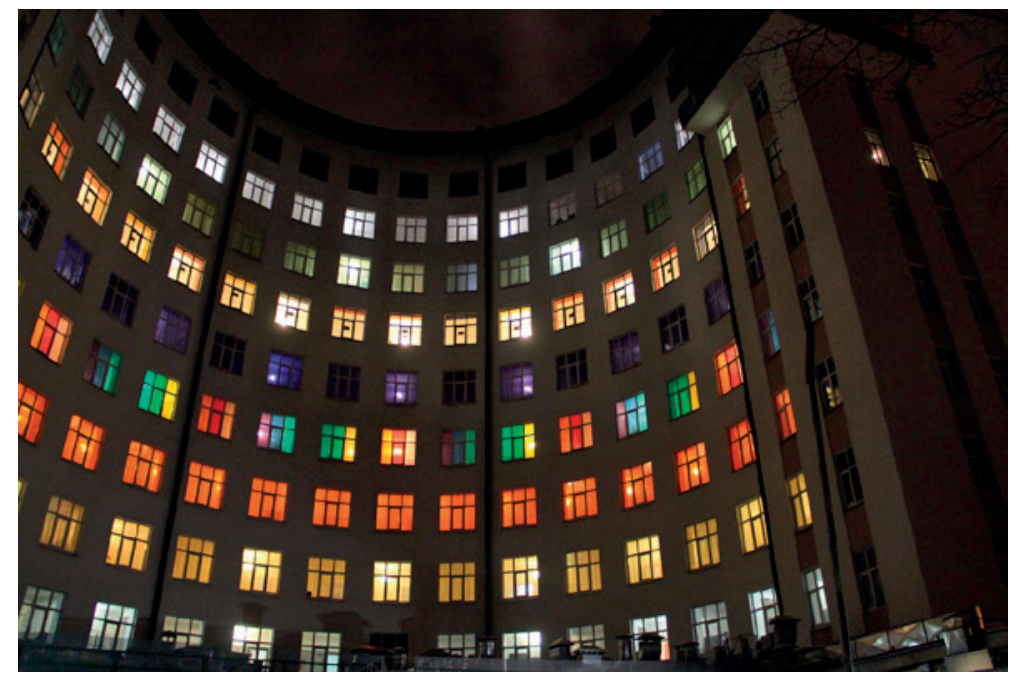

Figure 2. The art-work Zheng Yunhan "Whisper of Light" on the courtyard facade of the Iset Hotel. Photo by Liudmila Starostova, 2015 
The analysis of photographs taken during the decades of Soviet history, where the Iset Hotel is present, shows that people chose to take photos of the hotel exclusively from the front side, facing the square (see Figure 3 ).

The Biennial project prompted people to pay attention to the aesthetics of its back facade. A significant marker for the change in urban optics, as we believe, is the advertising of the local airline Ural Airlines in November 2016 on the facade of one of the buildings in the city center (see Figure 4).

The advertising itself with the image of a flying airplane contained the picture of the back facade of the Iset Hotel, rhyming with the trajectory of the aircraft. In addition, the photos of back façade of the Iset Hotel appeared in the Instagram after the Biennial too; they were made in the daytime and emphasized the special geometry of the building, underlined by the view of photographer.

The case with the transformation of the "sensory experience" (Rancière) of the Iset Hotel through artistic re-reading in the context of contemporary artistic language shows that a purely visual language of art - even without the use of historical and social narratives - may be sufficient to integrate the architecture with forgotten meanings into the important aesthetic contexts. The popularity of the hotel as an object of photographing can be easily explained by its photogenic nature, not only because of the fact that the artist of the 21 st century gave it the new expressiveness, but also because the spatial design in the form of a horseshoe; the

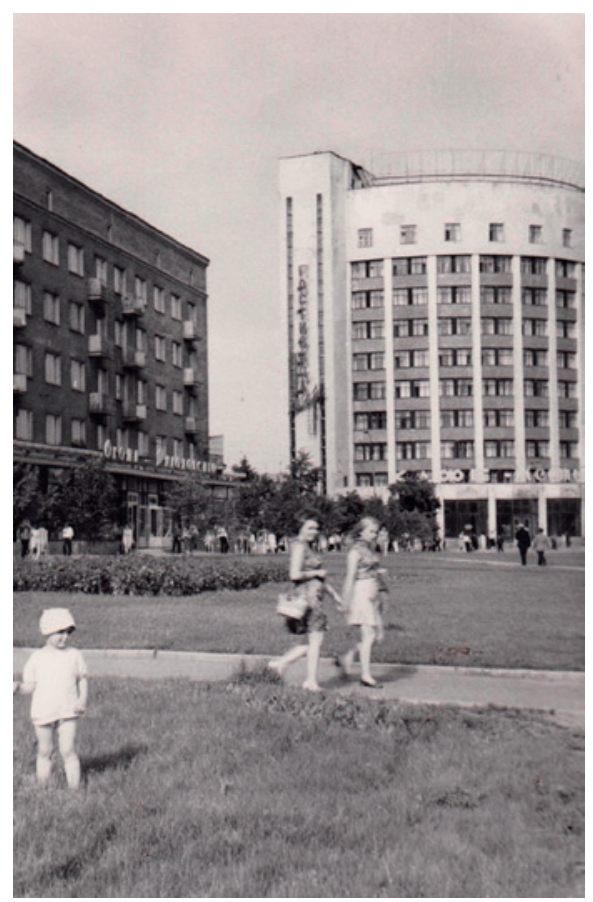

Figure 3. The Iset Hotel. Photo by Eduard Starostov, 1972 from the personal archive of Liudmila Starostova

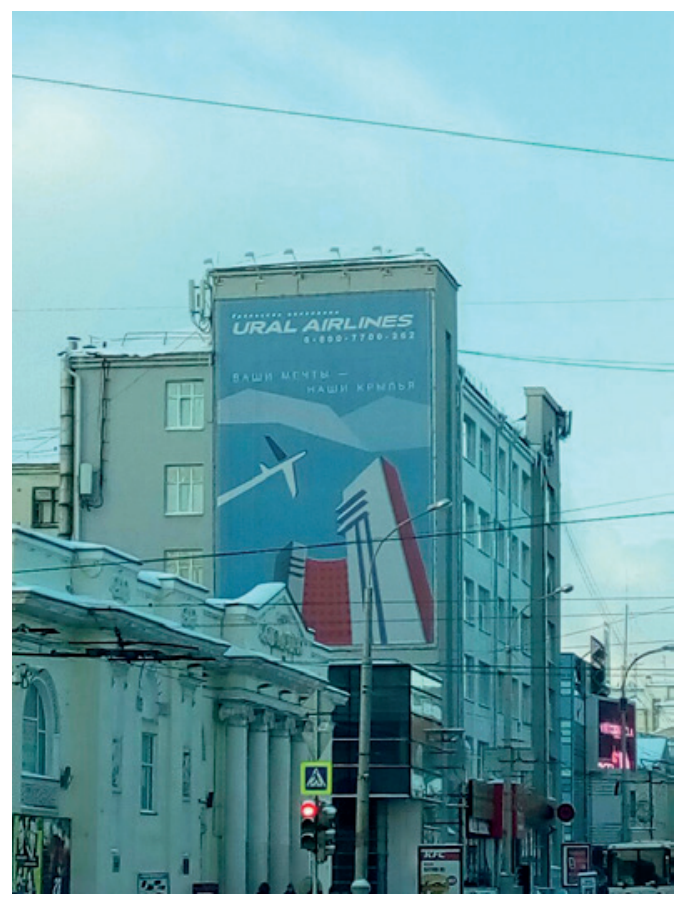

Figure 4 . The advertising of the local airline Ural Airlines with the picture of the Iset Hotel from the courtyard side. Photo by Liudmila Starostova, 2016 
purely pragmatic concept of the architect retains the appeal of its configuration in terms of abstract composition due to many factors: due to the dynamic form, offering a wide range of compositional solutions, due to the change in the angle of photography, due to the rhythm of windows and inter-window spaces and elegant geometry of the angular balconies located on the upper floors of a buildings back facade.

\section{Conclusions}

The analysis of modern narrative practices aimed at transcoding of the architectural avantgarde heritage of Yekaterinburg/Sverdlovsk reveals the productive potential of working with architecture as a form of crystallization of experience, which, on the one hand, accumulates in itself the vicissitudes of history, on the other hand, creates opportunities for transcoding and transforming narratives that open new perspectives for the formation of urban identity.

Yekaterinburg/Sverdlovsk constructivist complexes accumulate in themselves both the creative impulse of the avant-garde social and artistic trends of the 20th century, and the tragic experience of Joseph Stalin's social policy. Narratives that open a new optics to the understanding of constructivism, allow us to isolate the aesthetic value of these objects, to stratify the dramatic experience of history to work with the urban identity.

The creative narrativization of the constructivist heritage of Yekaterinburg/Sverdlovsk allows, on the one hand, to connect the identity of citizens with the past beyond the boundaries of traditional political myths and includes the city into a global architectural context and, on the other hand, opens the horizon for creative interpretations that meet modern contexts and support the spirit of the city.

\section{References}

1723.ru. (2008). Bolshoy Sverdlovsk 1930. Retrieved from http://www.1723.ru/read/books/sverdlovsk-1930.htm Ankersmit, F. (2003a). Istoriya i tropologiya: vzlet i padenie metafory. Moskva: Progress-tradiciya. Ankersmit, F. (2003b). Narrativnaya logika: semanticheskij analiz yazyka istorikov. Moskva: Ideya-press. Ankersmit, F. (2007). Vozvyshennyj istoricheskij opyt. Moskva: Evropa.

Assman, A. (2015). Dlinnaya ten proshlogo: memorialnaya kultura i istoricheskaya politika. Moskva: NLO.

Ben'yamin, V. (2000). O ponyatii istorii: novoe literaturnoe obozrenie. Novoe liternoe obozrenie, 46, 81-90.

Berseneva, V. (1972). Opisanie pamiatneykov arhitektury' sverdlovska. Sverdlovsk: Sverdlovskii arhitekturnyi institut.

Berseneva, V. (2000). Konstruktivisty I chekisty. Ural, 6, 161-164.

Buchli, V. (2013). An anthropology of architecture. London: Bloomsbury Academic.

Cohen, J.-L. (1992). Le Corbusier and the Mystique of the USSR: Theories and projects for Moscow, 1928-1936. Princeton: Princeton University Press.

Eco, U. (2006). Otsutstvuyushhaya struktura: vvedenie v semiologiyu. Sankt-Peterburg: Symposium.

Gan, A. (2016). Tektonika: formalnyj metod. Antologiya russkogo modernizma. Moskva-Yekaterinburg: Kabinetnyj uchenyj. 
Genette, G. (1998a). Figury. T. 1. Moskva: Izdatelstvo imeni Sabashnikovikh.

Genette, G. (1998b). Figury. T. 2. Moskva: Izdatelstvo imeni Sabashnikovikh.

Ginsburg, M. (1927). Itogi i perspektivy. Sovremennaya arxitektura, 4-5, 112, 114, 116, 118.

Ginzburg, M. (1923). Estetika sovremennosti. Arxitektura, 1-2, 3-6.

Ginzburg, M. (1926a). Funkcionalnyj metod I forma. Sovremennaya arxitektura, 4, 89-92.

Ginzburg, M. (1926b). Mezhdunarodnyj front sovremennoj arxitektury. Sovremennaya arxitektura, 2, 41-46.

Ginzburg, M. (1928). Konstruktivizm v arxitekture: pervaya konferenciya obshhestva sovremennyx arxitektorov. Doklad m. ya. Ginzburga. Sovremennaya arxitektura, 5, 143-145.

Ilchenko, M. (2016). Uralmash in the Architecture of the Soviet Avantgarde: An experiment in city construction in the 1920s and 1930s. Quaestio Rossica, 4(3), 55-71. https://doi.org/10.15826/qr.2016.3.175

Kačerauskas, T. (2008). Existential identity and memory of a nation. Limes: Cultural Regionalistics, 1(1), 5-14. https://doi.org/10.3846/2029-0187.2008.1.5-14

Khan-Magomedov, S. (2001). Arhitektura sovetskogo avangarda: sotcialnye problem. Moskva: Stroiizdat.

Landry, Ch. (2000). The creative city: A toolkit for urban innovators. London: Comedia/Earthscan.

Meerovich, M. (2008). Nakazanie zhilishchem: zhilishchnaia politika $v$ SSSR kak sredstvo upravleniia liudmi, 1917-1937. Moskva: Rospen.

Per, R., Cohen, Z. H.-L., \& Lambert, F. (2007). Poteriannyi avangard. Russkaia modernistskaia arhitektura, 1922-1932. Moskva: Tatlin.

Piskunova, L., Starostova, L., \& Yankov, I. (2015). Povsednevnye praktiki "gorodka chekistov", Katalog 3-i uralskoi industrialnoi biennale sovremennogo iskusstva, 9, 42-56.

Quinn, B. (2005). Art festivals and the city. Urban Studies, 42(5-6), 927-943. https://doi.org/10.1080/00420980500107250

Rancière, J. (2007). Razdelyaya chuvstvennoe. Sankt-Peterburg: Izdatelstvo evropejskogo universiteta.

Ricœur, P. (2000a). Vremya i rasskaz. T. 1. Moskva, Sankt-Peterburg: CGNII INION RAN: Kul'turnaya iniciativa, Universitetskaya kniga.

Ricœur, P. (2000b). Vremya i rasskaz. T. 1. Moskva, Sankt-Peterburg: CGNII INION RAN: Kul'turnaya iniciativa, Universitetskaya kniga.

Shelushinin, A. (1974). K istorii arhitektury Sverdlovska (konstruktivizm 1920-1930 gg). In Iz istorii khudogestvennoi kulturi Ekaterinburga - Sverdlovska (pp. 72-82). Sverdlovsk: Uralsky gosudarstvenny universitet.

Smirnov, L. (2008). Konstruktivizm v pamiatneykakh arhitektury sverdlovskoi oblasti. Yekaterinburg: Nauchno-issledovatelskii institut materialnoi kultury.

Starikov, A., Zvagelskaia, V., \& Tokmeninova, L. (1998). Yekaterinburg: istoriia goroda v arhitekture. Yekaterinburg: Izdatelstvo Sverdlovskogo arhitekturnogo instituta.

Starkov, I., Selivanova, A., \& Zueva, D. (2016). Danilovskii mostorg. Seriya: Nezamečenij avangard. Moskva: Centr avangard.

Starostova, L. (2016). K voprosu o kommemoracii sverdlovskogo konstructivisma: vzglyad cherez praktiku formirovaniya kulturnikh kvartalov. Izvestija UrFU 22-4(156), 163-174. Seriya 1: Problemi obrazovaniya, nauki i kulturi.

Timofeev, M. (2015). Nasledie ivanovo-voznesenskogo konstruktivizma kak resurs razvitiia. Problemy rossiiskoi istorii. Sotcialisticheskii gorod i sotciokulturnye aspekty urbanizatcii, 13, 310-320.

Tokarev, A. (2015). Arhitektura Rostova-na-Donu pervykh piatiletok 1920-1930-e gg. Rostov-na-Donu: Akademiya arkhitekturi i iskusstv Jugnogo federalnogo universiteta. 
Tokmeninova, L. (2012). Gorodok chekistov: zhiloi kompleks NKVD. Yekaterinburg: Tatlin.

Valevičius, M., \& Levickaite, R. (2011). Lighting of cultural heritage as a tool to exhibit historical architectural values in the context of creative industries (The case of Ukmergè). Limes: Borderland Studies, 4(2), 162-176. https://doi.org/10.3846/20290187.2011.639097

Yankov, I. (2011). Trauma and narrative fetishism as the source for creativity in the urban space. Limes: Borderland Studies, 4(2), 122-130. https://doi.org/10.3846/20290187.2011.633247

\title{
KONSTRUKTYVIZMO ARCHITEKTÜRA: ESTETINIŲ KODŲ IR NARATYVŲ KŪRYBINĖ TRANSFORMACIJA
}

\author{
Larisa PISKUNOVA, Liudmila STAROSTOVA, Igor YANKOV
}

\section{Santrauka}

Konstruktyvizmo (funkcionalizmo) architektūrai būdingos simbolinès reikšmès skiriamasis požymis, siejamas su modernistiniu projektu. Straipsnio autoriai atliko Sverdlovsko (Rusija) architektūrinio avangardo tyrimą, kuris parodė, kad silpnas konstruktyvistinių pastatų ir kompleksų istorinès ir kultūrinès svarbos suvokimas siejamas ne tik su žmonių sąmoningumo ir kūrybiškumo stoka, bet ir su nepakankamu jų estetinès vertès sureikšminimu.

Specifiniams architektūriniams projektams skirtų erdvès planavimo sprendimų tyrimas atskleidžia tikrąją konceptualiąją pastatų estetiką. Be to, konstruktyvistinių architektūrinių kompleksų socialinès istorijos tyrimas, atliktas straipsnio autorių, padejjo nustatyti ir artikuliuoti jų kultūrinę ir istorinę reikšmę bei kūrybiškai išryškinti šių architektūrinių nuorodų žymeklių vizualinį suvokimą miesto erdvèje. Autoriai taip pat remiasi savo pačių parodų ir publikacijų rengimo bei ekskursine patirtimi. Šios patirties analize autoriams leidžia prieiti prie tam tikrų išvadų, kaip žmonès vizualiai suvokia konstruktyvistinių monumentų raidos ir kaitos praktiką.

Straipsnyje pristatomo požiūrio į architektūros tyrimą originalumą sudaro rẻmimasis socialine architektūros istorija, padedančia padidinti estetinę jos vertę.

Reikšminiai žodžiai: estetinis kodas, avangardo architektūra, miestas, konstruktyvizmas, naratyvas, socialinè patirtis. 